\title{
IDENTIFIKASI DAN POTENSI KERUSAKAN RAYAP PADA TANAMAN TEMBESU (Fagraea fragrans) DI KEBUN PERCOBAAN WAY HANAKAU, LAMPUNG UTARA
}

\author{
(Termite Identification and Potential Damage on Tembesu Plantation in \\ Experiment Field of Way Hanakau, North Lampung)
}

\author{
Asmaliyah $^{1)}$, Andika Imanullah ${ }^{1)}$ dan/and Wida Darwiati ${ }^{2)}$ \\ ${ }^{1)}$ Balai Penelitian Kehutanan Palembang \\ Jl. Kol. H. Burlian Km. 6,5 Punti Kayu PO. Box. 179, Palembang, Sumatera Selatan \\ Telp./Fax. 0711-414864 \\ ${ }^{2)}$ Pusat Penelitian dan Pengembangan Peningkatan Produktivitas Hutan, Bogor \\ Jl. Gunung Batu No. 5, Bogor 16610 \\ Telp. 0251-8631238, Fax. 0251-7520005
}

Naskah masuk : 3 Desember 2011; Naskah diterima : 30 November 2012

\begin{abstract}
Tembesu (Fagraea fragrans Roxb) is one of the local tree species that has fairly economic and ecological value. It is promising to be developed for the area in South Sumatera, Jambi and Lampung. However, developing plantation of this species is hindered by damage due to termites. Therefore, it is necessary to carry out research, since there are no reports on the species of termites that attack tembesu and its pest control management does not exist. The results showed that it was found that termite attacking tembesu plants in the experiment garden of Way Hanakau, North Lampung belongs to species of Nasutitermes matangensis (Isoptera: Termitidae). This termite is catagorized as a quite important pest due to its potentials to cause economic losses and threat the development of tembesu plantation forests.
\end{abstract}

\section{Keywords: Identify, tembesu, termitidae}

\begin{abstract}
ABSTRAK
Tembesu (Fagraea fragrans Roxb) merupakan salah satu jenis tanaman lokal yang cukup potensial untuk dikembangkan di daerah Sumatera Selatan, Jambi dan Lampung, karena jenis ini merupakan jenis asli di daerah tersebut dan mempunyai keunggulan baik dari sisi ekologi maupun nilai ekonominya. Namun dalam pengembangannya dijumpai adanya serangan hama rayap yang dikhawatirkan akan membahayakan tanaman. Oleh karena itu perlu dukungan riset, karena sampai saat ini laporan tentang jenis rayap yang menyerang tembesu dan pengendaliannya belum ada. Hasil penelitian menunjukkan bahwa jenis rayap yang ditemukan menyerang tanaman tembesu di kebun percobaan Way Hanakau, Lampung Utara adalah rayap Nasutitermes matangensis (Isoptera; Termitidae). Rayap ini termasuk hama yang cukup penting karena berpotensi menyebabkan kerugian secara ekonomis dan menurunkan target pembangunan hutan tanaman tembesu.
\end{abstract}

Kata kunci : Identifikasi, tembesu, rayap

\section{PENDAHULUAN}

Tembesu (Fagraea fragrans Roxb) merupakan salah satu jenis tanaman lokal yang cukup potensial untuk dikembangkan di daerah Sumatera Selatan, Jambi dan Lampung, karena jenis ini merupakan jenis asli di daerah tersebut dan mempunyai keunggulan baik dalam sisi ekologi maupun nilai ekonominya karena telah lama dikenal masyarakat. Kayu tembesu dapat digunakan sebagai bahan konstruksi berat, balok jembatan, tiang-tiang rumah, lantai, dan barang bubutan (Martawijaya et al., 1989).

Saat ini potensi tegakan tembesu sudah sangat menurun di berbagai daerah sebaran alaminya, oleh karenanya perlu dikembangkan dengan membangun hutan tanaman tembesu atau penanaman di hutan rakyat. Saat ini sebagian besar 
areal penanaman tembesu di daerah Sumatera Selatan, Jambi dan Lampung dilakukan oleh rakyat melalui anakan alam yang tumbuh dari akar atau cabutan dalam pola campuran dan pola agroforestri.

Pembangunan hutan tanaman seringkali menghadapi kendala teknis, salah satunya adalah ancaman adanya serangan hama. Oleh karena itu kegiatan pengendalian sangat penting dilakukan untuk mendukung keberhasilan pembangunan hutan tanaman khususnya peningkatan produktivitas. Kegiatan pengendalian dapat menekan peluang muncul dan berkembangnya serangan hama sehingga kerugian secara ekonomis dapat dikurangi. Salah satu kunci keberhasilan kegiatan pengendalian tersebut adalah diketahuinya informasi tentang jenis hama yang menyerang.

Berdasarkan data yang dikumpulkan sejak tahun 2006, ketika tanaman tembesu berumur tiga tahun ditemukan adanya serangan di kebun percobaan Way Hanakau, Lampung Utara. Kondisi tersebut cenderung mengindikasikan serangan rayap ini akan semakin meluas dan dikhawatirkan dapat mempengaruhi keberhasilan penanaman, sehingga perlu adanya antisipasi dini. Hasil penelitian Sekamatte (2001) dalam Owusu et al. (2008), menunjukkan adanya kehilangan hasil sebesar 50 sampai $100 \%$ pada tanaman pertanian dan tegakan pohon akibat serangan rayap. Oleh karena itu perlu dukungan riset berkaitan dengan permasalahan ini, karena sampai saat ini laporan tentang jenis rayap yang menyerang tanaman tembesu dan pengendaliannya belum ada.

Bertitik tolak dari kondisi ini, maka tujuan penelitian ini adalah untuk mengetahui jenis rayap yang menyerang tanaman tembesu, luas serangan dan dampak kerusakannya pada tanaman. Informasi ini diharapkan dapat menjadi acuan untuk strategi pengendalian serangan rayap di lapangan.

\section{BAHAN DAN METODE}

\section{A. Tempat dan Waktu}

Penelitian ini dilakukan di Kebun Percobaan Way Hanakau pada plot uji coba penanaman tembesu tahun tanam 2003. Luas areal plot uji coba ini seluas 2 ha dengan jarak tanam $3 \mathrm{~m} \times 3 \mathrm{~m}$, dimana luasan areal penelitian ini dibagi menjadi 3 blok dan masing-masing blok terdiri dari 6 petak coba, 1 petak coba terdiri dari 25 tanaman.
Berdasarkan administrasi pemerintahan Kebun Percobaan Way Hanakau berada di Desa Hanakau Jaya, Kecamatan Sungkai Utara, Kabupaten Way Kanan, Provinsi Lampung, dan secara geografis terletak diantara $04^{\circ} 32^{\prime} 05,3^{\prime \prime}-04^{\circ} 32^{\prime} 07,6$ " LS dan $104^{\circ} 44^{\prime} 41,9^{\prime \prime}-104^{\circ} 44^{\prime} 26,1^{\prime \prime}$ BT. Luas kebun percobaan Way Hanakau saat ini adalah 47,12 Ha dan termasuk pada kawasan Hutan Produksi Terbatas (register 46). Jenis tanah yang ada adalah podsolik merah kuning, dengan keadaan topografi datar dari $0 \%-16 \%$, Pupuk dasar yang diberikan sebelum penanaman adalah pupuk kandang dan NPK. Waktu penelitian dilakukan dari tahun 2008 sampai 2010.

\section{B. Bahan dan Alat Penelitian}

Bahan yang digunakan dalam penelitian ini adalah alkohol, kotak plastik, kertas koran, cat dan tally sheet. Alat yang digunakan adalah handcounter, kuas, parang, cangkul, kamera dan alat tulis.

\section{Metode}

Penelitian dilakukan dengan metode survey pada plot pengamatan yang terdiri dari 450 tanaman tembesu. Parameter yang diamati adalah jenis rayap yang menyerang, bentuk kerusakan yang tampak pada tanaman yang terserang, luas serangan dan pola sebaran. Pengumpulan data dilakukan secara sensus (100\%) pada plot uji coba penanaman tembesu tahun tanam 2003. Analisis data dilakukan secara deskriptif.

\section{Identifikasi rayap}

Identifkasi ini dilakukan untuk mengetahui jenis rayap yang menyerang tanaman tembesu. Sampel rayap diambil dari gundukan sarang yang terdapat pada batang tembesu dengan cara memotong gundukan sarang tersebut yang didalamnya terdapat koloni rayap berupa telur, kasta pekerja, kasta prajurit dan laron. Identifikasi dilakukan melalui pengenalan gejala serangan di lapangan dan secara morfologi yang dilakukan di Museum Zoologi Entomologi Bogor, Widya Satwaloka Lembaga Ilmu Pengetahuan Indonesia, LIPI.

\section{Luas serangan}

Pengamatan luas serangan ini dilakukan untuk mengetahui persentase jumlah tanaman yang terserang setiap tahunnya. Data ini digunakan untuk melihat potensi serangan rayap pada tanaman tembesu. Data luas serangan diperoleh dengan cara menghitung jumlah tanaman yang 
terserang rayap dibagi jumlah seluruh tanaman yang ada pada setiap blok di kali 100 persen atau :

LS $=\frac{\text { Jumlah tanaman yang terserang pada setiap lokasi pertanaman }}{\text { Jumlah } \text { seluruh tanaman dalam suatu petak ukur }} \times 100 \%$

\section{Pola sebaran}

Data pola sebaran ini diperoleh dengan cara menandai setiap tanaman yang terserang pada setiap kali pengamatan. Data pola sebaran ini digunakan untuk mengetahui potensi serangan rayap dan sebagai salah satu cara untuk mencari pengendalian yang terbaik.

\section{HASIL DAN PEMBAHASAN}

\section{A. Identifikasi Rayap}

Berdasarkan hasil identifkasi di Laboratorium Museum Zoologi Entomologi Bogor, Widya Satwaloka LIPI maka jenis rayap yang ditemukan adalah Nasutitermes matangensis Haviland. Jenis rayap ini termasuk dalam ordo Isoptera, famili Termitidae, subfamili Nasutitermitinae dan genus Nasutitermes. Menurut Jones dan Prasetyo (2002), ciri morfologi rayap yang termasuk kelompok rayap tanah (subterranean termite), pemakan kayu (wood feeders) dan sarangnya berada di pohon (arboreal nest), yaitu (1) kepala berwarna kuning berbentuk bulat; (2) membentuk nasut dengan fontanel di ujungnya, panjang kepala dengan nasut $1,25 \mathrm{~mm}$, yang tanpa nasut $0,65 \mathrm{~mm}$; (3) lebar kepala 0,72 mm; (4) antena pendek terdiri dari 12-13 ruas; (5) ruas ketiga lebih panjang dari ruas kedua, ruas keempat lebih pendek dari ruas ketiga. Nasut prajurit berbentuk kerucut dengan bagian pangkal menebal dan agak melengkung (Nandika et al., 2003). Rayap ini tersebar luas dari Semenanjung Malaya, Vietnam, Sumatera, Jawa, Kalimantan sampai Nikobar dan Pulau Chrismas (Samudera Hindia) (Roonwall 1970 dalam Pribadi, 2009).

Hasil penelitian Chuah et al. (1989), menunjukkan bahwa rayap ini mengandung kimia semio yang bekerja secara interspesifik berupa limonene dan myrcene yang berfungsi untuk pertahanan diri dari species lain yang akan membahayakan mereka atau predator. Kimia semio ini berdasarkan kerjanya digolongkan ke dalam kelompok senyawa kimia alelo yang menurut fungsinya termasuk dalam kelompok allomon (Oka, 1995). Koloni dalam famili ini sangat besar dengan kasta dan ukuran yang jelas berbeda di dalam gundukan sarang.

Beberapa jenis Nasutitermes atau Eutermes ini hidup di pohon, prajuritnya disebut nasutes. Sarangnya banyak ditemukan pada bagian atas pohon atau di atap bangunan, juga ditemukan di tanah antara akar dan tunggul pohon. Sarangnya seringkali terbuat dari bahan seperti kertas. Beberapa species Nasutitermes ini umumnya ditemukan pada pohon-pohon penghasil buah, pelindung dan yang hias di taman. Namun serangan rayap ini secara ekonomi tidak merugikan karena tidak masuk terlalu kedalam teras kayu (Kalshoven, 1981). Menurut Tarumingkeng (1971 dalam Suin, 1992), rayap $N$. matangensis ini selain ditemukan pada kayu-kayu lapuk juga dapat menyerang kayu pada kontruksi bangunan.

Serangan rayap pada tanaman di lapangan tampak jelas terlihat dengan adanya sarang-sarang rayap yang terbuat dari tanah, pada pangkal batang, batang pohon bagian bawah sampai batang pohon bagian atas dan terdapat juga pada cabang pohon. Akibat serangan rayap ini batang mengalami rusak berat, rapuh dan berlubang-lubang, bahkan pada serangan berat dapat mengakibatkan kematian tanaman (Gambar 1).

Sarang rayap $N$. matangensis ini semakin lama akan semakin membesar, membentuk gundukan, seiring dengan semakin bertambahnya populasi rayap. Gundukan rayap ini dapat ditemukan pada permukaan tanah, batang pohon bagian bawah dan bagian atas (Gambar 2). Hasil penelitian yang dilakukan Hariri et al. (2002), juga mendapatkan adanya sarang rayap $N$. matangensis di permukaan tanah, di bawah potongan kayu ranting dan tunggul yang melapuk serta terdapat juga pada batang/cabang/ranting hidup. 


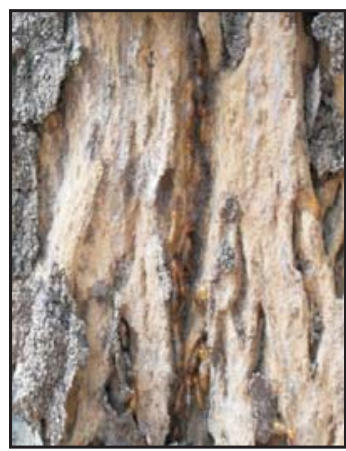

a

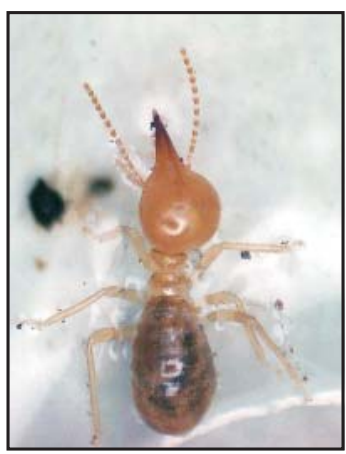

b

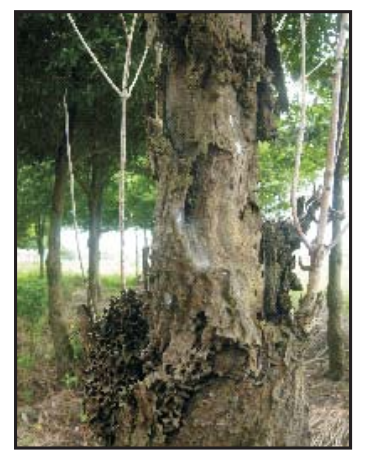

$\mathrm{c}$

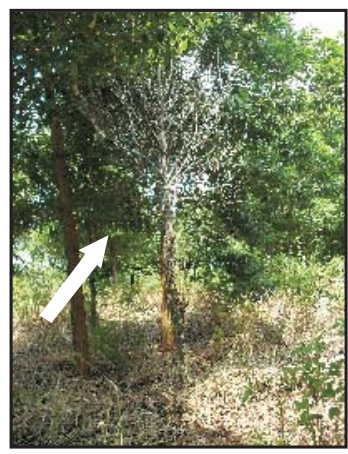

d

Gambar(Figure) 1. Bentuk kerusakan akibat serangan rayap N. matangensis pada tanaman tembesu: a. bentuk kerusakan pada batang; b. rayap $N$. matangensis; c. batang yang rapuh dan berlubang; $d$. pohon tembesu yang mati akibat serangan rayap (The form of damage caused by $\underline{N}$. matangensis termite on tembesu plantation: a. the form of damage on stem; $b$. N. matangensis; $c$. brittle and hollow stem; $d$. tembesu tree that died due to termite attack)

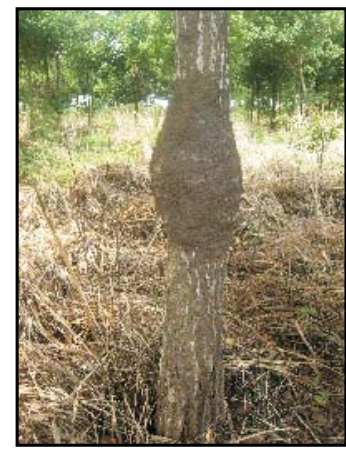

$\mathbf{a}$

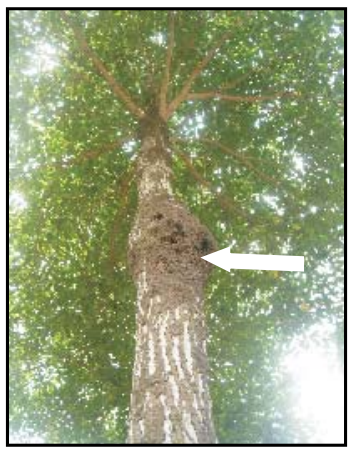

b

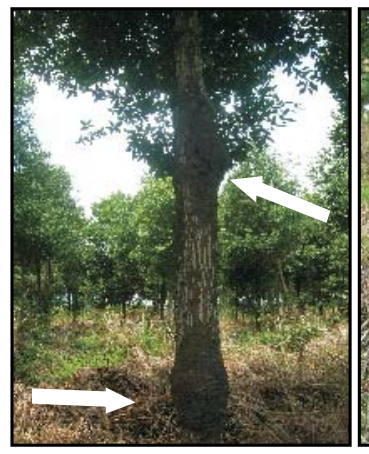

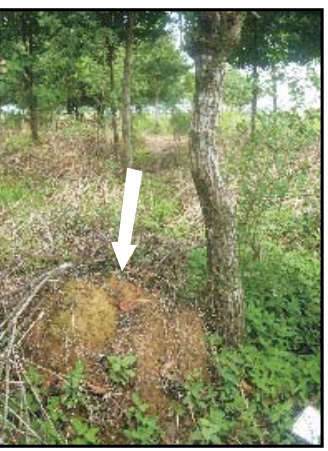

d

Gambar(Figure) 2. Gundukan sarang rayap: a. pada batang, b. bagian atas pohon, c. bagian bawah dan atas pohon, d. permukaan tanah (Termite nest mound: $a$. on stem; $b$. on the top of tree; c. the bottom of tree; $d$. on soil surface)

\section{B. Luas serangan}

Berdasarkan hasil perhitungan rata-rata luas serangan atau persentase serangan rayap mulai tahun 2008 sampai dengan 2010 dapat dilihat pada Tabel 1. Tabel 1 menunjukkan bahwa adanya pertambahan luas serangan rayap pada tahun 2009 pada semua blok dan ada kecenderungan terjadi penurunan pertambahan luas serangan pada tahun 2010 (Gambar 3). Terjadinya serangan rayap pada areal pertanaman tembesu di kebun percobaan Way Hanakau ini diduga erat kaitannya dengan kondisi lingkungan areal tersebut yang sangat mendukung kehidupan rayap. Kondisi lingkungan tersebut berupa ketebalan serasah yang merupakan tempat perlindungan dan sumber makanan, kelembaban udara sekitar tanaman yang tinggi dan adanya tonggak-tonggak kayu yang merupakan sumber inokulum rayap.

Meluasnya serangan rayap pada tahun 2009, diduga disebabkan faktor kelembaban tanah yang semakin tinggi karena tajuk antar tanaman sudah saling menutupi. Kondisi ini sangat mendukung untuk kehidupan dan aktivitas rayap sehingga populasi rayap semakin tinggi. Hal ini diindikasikan oleh semakin banyaknya jumlah tanaman yang terserang (Tabel 2) serta banyaknya jumlah gundukan sarang rayap baik di permukaan tanah maupun di batang (Tabel 3). Banyaknya jumlah pohon yang mati diakibatkan karena tingginya populasi rayap yang terjadi pada tahun sebelumnya. Beberapa pohon yang sudah terserang cukup berat, menjadi semakin berat, bagian batang yang rusak sudah di atas $80 \%$, akibatnya pohon mati. 
Tabel(Table) 1. Persentase serangan rayap pada tanaman tembesu umur 3 tahun di kebun percobaan Way Hanakau, Lampung Utara (Termite attack percentage on tembesu plantation that planted at 3 years old in experiment field of Way Hanakau, North Lampung)

\begin{tabular}{|c|c|c|c|c|}
\hline \multirow{3}{*}{ Blok } & \multicolumn{4}{|c|}{ Persentase Serangan (Attack Percentage) } \\
\cline { 2 - 5 } & Tahun 2008 (\%) & Tahun 2009 (\%) & \multicolumn{2}{|c|}{ Tahun 2010 (\%) } \\
\cline { 2 - 5 } & & & Agustus & Desember \\
\hline I & 20,17 & 69,30 & 71,93 & 81,58 \\
\hline II & 35,37 & 59,86 & 76,87 & 78,91 \\
\hline III & 23,81 & 41,90 & 60,00 & 75,24 \\
\hline Rata-rata & 26,45 & 57,02 & 69,60 & 78,58 \\
\hline
\end{tabular}

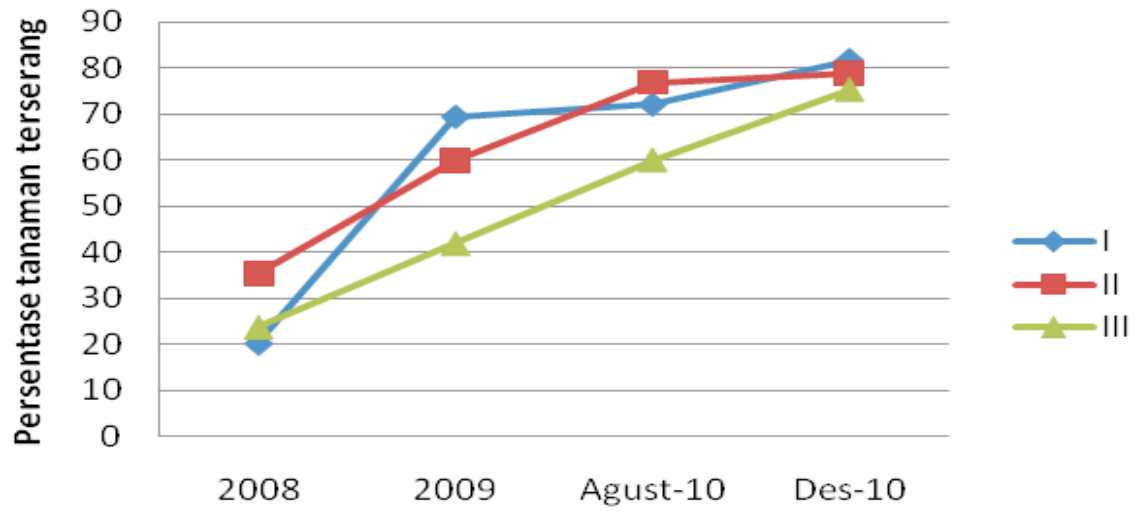

Tahun Pengamatan

Gambar(Figure) 3. Persentase serangan rayap pada tanaman tembesu di kebun percobaan Way Hanakau, Lampung Utara (I, II, III = Blok) (Termite attack percentage on tembesu plantation in experiment field of Way Hanakau, North Lampung $(I, I I, I I I=$ Block $))$

Pohon yang mati ditemukan pada semua blok: blok I sebanyak 1 pohon, blok II sebanyak 2 pohon dan blok III sebanyak 2 pohon.

Gambar 3 menunjukkan bahwa penurunan luas serangan rayap tahun 2010, diduga kuat karena adanya kegiatan pemangkasan dan pembersihan areal yang dilakukan pada bulan Juli tahun 2010 . Kegiatan pemangkasan ini menyebabkan di sekitar tanaman menjadi lebih terbuka sehingga sinar matahari dapat lebih banyak sampai ke permukaan tanah atau ke pangkal batang yang berdampak pada penurunan kelembaban tanah di areal tersebut. Kondisi ini yang mengakibatkan kehidupan dan aktivitas rayap menjadi terhambat sehingga terjadi penurunan jumlah tanaman yang terserang (Gambar 4).

Menurut Jones dan Prasetyo (2002), penutupan kanopi merupakan faktor utama yang menyebabkan terjadinya kelimpahan rayap pada suatu areal hutan tanaman. Pernyataan ini ditunjukkan oleh ditemukannya $N$. matangensis pada areal hutan yang sedang berlangsung penebangan, sedangkan pada areal yang sudah lama dilakukan penebangan (areal sudah lama terbuka) rayap ini tidak ditemukan. Begitu juga hasil penelitian Pribadi (2009), kelimpahan rayap paling tinggi ditemukan pada areal hutan lindung dengan kondisi tegakan yang rapat dibandingkan pada areal wana wisata, hutan produksi, agroforestri dan pemukiman dengan kondisi tajuk agak terbuka. Selain kondisi tajuk, maka kondisi tumbuhan bawah juga diduga erat kaitannya dengan menurunnya populasi rayap karena dengan kegiatan ini tumbuhan bawah, serasah dan gundukan sarang rayap yang ada di permukaan tanah dikurangi atau dimusnahkan.

Menurunnya pertambahan luas serangan rayap ini kemungkinan juga disebabkan karena adanya semut gramang (Anoplolepis $=$ Plagiolepis longipes Jerd) yang merupakan musuh alami dari rayap, hal ini terlihat bahwa di lapangan ditemukan semut gramang yang sedang memakan telur-telur rayap di dalam gundukan sarang yang terdapat baik di tanah maupun di pohon. Menurut Kalshoven (1981), kelompok semut yang termasuk dalam ordo Hymenoptera, sub ordo 
Tabel(Table) 2. Jumlah tanaman yang terserang rayap pada tanaman tembesu umur 3 tahun di kebun percobaan Way Hanakau, Lampung Utara (The number of plants attacked by termites in tembesu plantation at 3 years old in the field experiment of Way Hanakau, Lampung Utara)

\begin{tabular}{|c|c|c|c|c|c|c|c|c|c|}
\hline \multirow{4}{*}{ No. } & \multirow{4}{*}{ Blok } & \multicolumn{2}{|c|}{ Tahun 2008} & \multicolumn{2}{|c|}{ Tahun 2009} & \multicolumn{4}{|c|}{ Tahun 2010} \\
\hline & & & & & & \multirow{2}{*}{\multicolumn{2}{|c|}{$\begin{array}{c}\text { Agustus } \\
\text { Jumlah Tanaman } \\
\text { (The Number of } \\
\text { Plants) }\end{array}$}} & \multirow{2}{*}{\multicolumn{2}{|c|}{$\begin{array}{c}\text { Desember } \\
\text { Jumlah Tanaman } \\
\text { (The Number of } \\
\text { Plants) }\end{array}$}} \\
\hline & & \multicolumn{2}{|c|}{$\begin{array}{c}\text { Jumlah Tanaman } \\
\text { (The Number of Plants) }\end{array}$} & \multicolumn{2}{|c|}{$\begin{array}{c}\text { Jumlah Tanaman } \\
\text { (The Number of Plants) }\end{array}$} & & & & \\
\hline & & hidup & terserang & hidup & terserang & hidup & terserang & hidup & terserang \\
\hline 1. & $\mathrm{I}$ & 114 & 23 & 114 & $79(56)$ & 114 & $82(3) / 1$ & 114 & $93(11)$ \\
\hline 2. & II & 147 & $52 / 2$ & 147 & $88(36)$ & 147 & $113(27)$ & 147 & $116(3)$ \\
\hline 3. & III & 105 & 25 & 105 & 44 (19) & 105 & $63(19) / 2$ & 105 & $79(16)$ \\
\hline
\end{tabular}

Keterangan (Remarks): Angka dalam kurung adalah pertambahan jumlah tanaman yang terserang; angka dibelakang garis miring adalah jumlah tanaman yang mati akibat serangan rayap (The number in brackets are in the number of plants attacked; numbers behind the slash is the number of plants that die from termite attack)

Tabel (Table) 3. Jumlah gundukan sarang rayap pada tanaman tembesu umur 3 tahun di kebun percobaan Way Hanakau, Lampung Utara (The number of termite nests mound on tembesu at 3 years old in the experiment field of Way Hanakau, North Lampung)

\begin{tabular}{|c|c|c|c|c|c|c|c|c|c|}
\hline \multirow{4}{*}{ No. } & \multirow{4}{*}{ Blok } & \multicolumn{2}{|c|}{ Tahun 2008} & \multicolumn{2}{|c|}{ Tahun 2009} & \multicolumn{4}{|c|}{ Tahun 2010} \\
\hline & & & & & & \multirow{2}{*}{\multicolumn{2}{|c|}{$\begin{array}{c}\text { Agustus } \\
\text { Jumlah sarang } \\
\text { (The number of } \\
\text { termitenests) }\end{array}$}} & \multirow{2}{*}{\multicolumn{2}{|c|}{$\begin{array}{c}\text { Desember } \\
\text { Jumlah sarang } \\
\text { (The number of } \\
\text { termitenests) }\end{array}$}} \\
\hline & & \multicolumn{2}{|c|}{$\begin{array}{c}\text { Jumlah sarang } \\
\text { (The number of } \\
\text { termitenests) }\end{array}$} & \multicolumn{2}{|c|}{$\begin{array}{c}\text { Jumlah sarang } \\
\text { (The number of } \\
\text { termitenests) }\end{array}$} & & & & \\
\hline & & Tanah & Pohon & Tanah & Pohon & Tanah & Pohon & Tanah & Pohon \\
\hline 1. & $\mathrm{I}$ & 3 & 2 & 3 & 8 & - & 8 & - & 7 \\
\hline 2. & II & 4 & 2 & 4 & 8 & - & 9 & - & 9 \\
\hline 3. & III & 3 & 1 & 3 & 3 & - & 4 & - & 4 \\
\hline
\end{tabular}

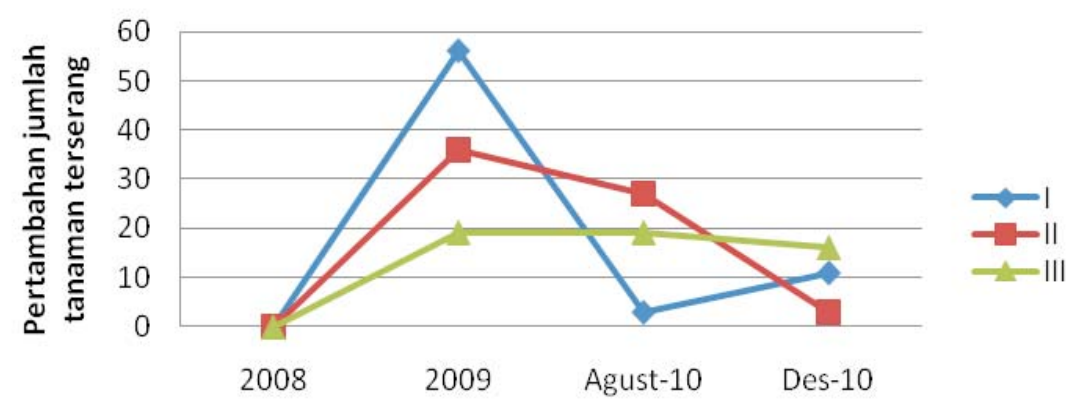

Tahun Pengamatan

Gambar(Figure) 4. Pertambahan jumlah tanaman tembesu yang terserang rayap di kebun percobaan Way Hanakau, Lampung Utara (I, II, III = Blok) (The number of plants are attacked by termites in the experiment field of Way Hanakau, North Lampung (I, II, III = Block))

Formicoidea, peranannya di daerah tropik sangat penting dalam ekologi dari banyak serangga hama, salah satunya adalah sebagai musuh alami dari serangga pemakan tanaman (Phytophagous) diantaranya rayap. Semut gramang ini berwarna coklat, kakinya panjang, badannya langsing dan panjangnya sekitar $0,35-0,40 \mathrm{~cm}$. Semut ini bisa hidup di dataran rendah sampai ketinggian 1200 $\mathrm{m}$ dpl. Semut ini biasanya membuat sarang di serasah, kompos atau kayu yang telah lapuk (Kalshoven, 1981; Pracaya, 2003).

\section{Pola Sebaran Rayap}

Pola sebaran rayap ini menyebar merata di seluruh areal pertanaman tembesu dengan pola penularan diawali dari tanaman terserang yang berdekatan dengan tanaman yang sakit. Ber- 

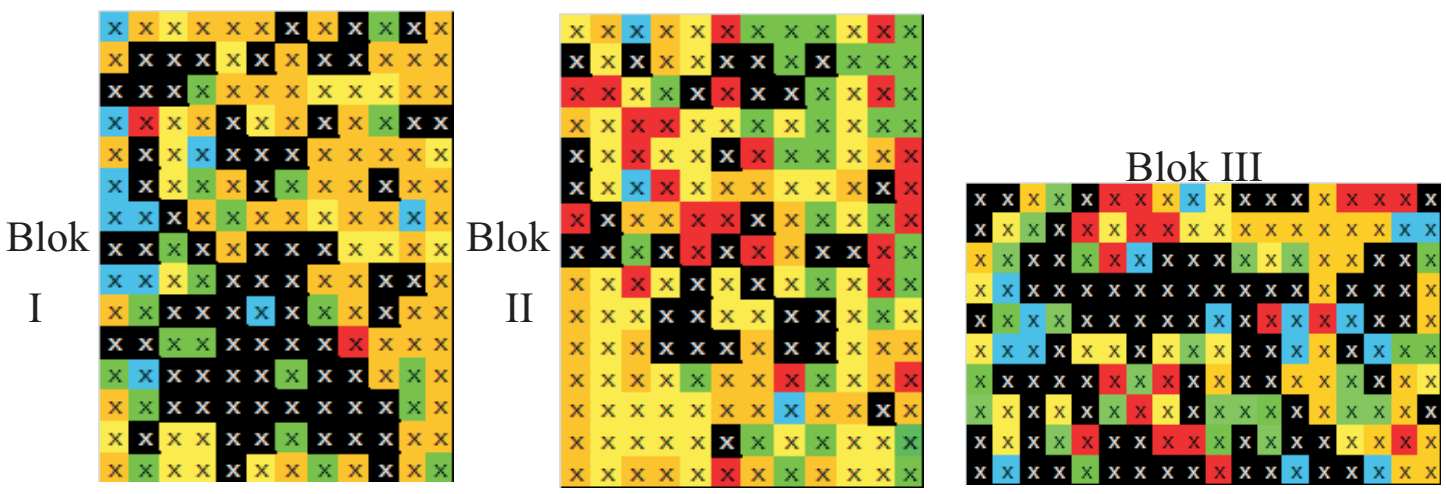

Keterangan (Remarks): $\quad$ serangan rayap tahun 2008; 2010 (Agustus); hidup/sehat

Gambar(Figure) 5. Pola penyebaran serangan rayap pada tanaman tembesu (The pattern of spread of termite attack on tembesu plantation)

dasarkan hasil pengamatan di lapangan terlihat jelas pertambahan jumlah tanaman yang terserang dari pengamatan sebelumnya terjadi pada tanaman yang berdekatan dengan tanaman yang telah terserang (Gambar 5). Penyebaran rayap termasuk cukup cepat karena dalam jangka waktu 5 tahun, luas serangan rayap sudah mencapai rata-rata $78,67 \%$.

\section{Teknik Pengendalian}

Berdasarkan hasil yang diperoleh maka rayap yang termasuk jenis hama yang cukup penting pada tanaman tembesu berpotensi menyebabkan kerugian secara ekonomis dan kegagalan pembangunan hutan tanaman tembesu. Oleh karena itu perlu diantisipasi sejak dini dengan mencegah atau mengurangi agar serangan rayap tidak sampai berkembang dan meluas lagi.

Beberapa teknik pengendalian yang bisa dilakukan adalah: 1) mengeradikasi pohon-pohon yang telah mati akibat serangan rayap, tunggultunggul bekas tanaman dan sarang-sarang rayap dari areal pertanaman, karena dapat menjadi sumber infeksi; 2) melakukan kegiatan pemangkasan untuk mengurangi penutupan tajuk, sehingga sinar matahari bisa lebih banyak sampai ke permukaan tanah atau ke pangkal batang karena pada kondisi penutupan kanopi agak terbuka, maka fluktuasi suhu dan kelembaban yang tinggi akan mengganggu kehidupan dan aktivitas rayap (Escoubas, 2000); 3) menggunakan insektisida mikroba cendawan Metarr-hizium anisopliae (Kartika et al., 2007), isolat cendawan entomopatogenik Peacilomyces fumosoroseus dan Beau- veria bassiana (Rayati dan Widayat, 2006), yang diaplikasikan dengan cara ditabur atau disemprot; dan 4) bila diperlukan dapat menggunakan insektisida kimia yang berbahan aktif imidakloprid (http://www. chemigarindustry.com).

\section{KESIMPULAN}

\section{A. Kesimpulan}

1. Rayap yang menyerang tanaman tembesu umur 3 tahun di lapangan adalah jenis Nasutitermes matangensis.

2. Luas serangan rayap semakin tinggi dengan tingginya penutupan tajuk tanaman.

3. Pola sebaran rayap yang menyerang tanaman tembesu di lapangan terjadinya dengan pola infeksi dari tanah tanaman yang berdekatan dengan tanaman yang terserang.

4. Teknik pengendalian dapat dilakukan dengan cara-cara komprehensif dari teknik yang dilakukan oleh pelaksana lapangan dan penelitian sebelumnya

\section{B. Saran}

1. Perlu penelitian yang lebih intensif untuk mengetahui faktor yang paling dominan menyebabkan muncul dan berkembangnya serangan rayap, sehingga tindakan pengendalian yang dilakukan bisa lebih terarah dan efektif.

2. Langkah antisipasi pada hutan tanaman tembesu yang sudah ada, khususnya tanaman tembesu yang sudah berumur sekitar 3 tahun, perlu monitoring yang intensif, agar muncul dan berkembangnya serangan rayap dapat segera diantisipasi. Apabila ditemukan ada- 
nya serangan rayap, sesegera mungkin rayap dieradikasi dari areal pertanaman dan dimusnahkan sehingga serangan rayap tidak sempat berkembang dan meluas.

\section{DAFTAR PUSTAKA}

Chuah, C.H., S.H. Goh dan Y.P. Tho. 1989. Interspecific Variation in Defense Secretions of Malaysian Termites from the Genus Nasutitermes (Isoptera; Nasutitermitinae). Journal Chemical Ecology, Vol.15, No.2, tahun 1989. http://www.pherobase.net/. Akses tanggal 12 Desember 2010.

Escoubas, P., L. Lajide dan J. Mizutani. 2000. Termite Antifeedant Activity in Aframomum melequeta. Phytochemistry, Vol.40, No.4, November 1995. Available online 28 April 2000.

Hariri,A.M., F. X. Susilo dan H. Sudarsono. 2002. Studi Populasi Rayap pada Pertanaman Lada di Kecamatan Baradatu, Way Kanan Lampung. Laporan Penelitian DIKS. Fakultas Pertanian. Universitas Lampung, Departemen Pendidikan Nasional.

http://www.chemigarindustry.com. 2011. Rayap dan pengendaliannya. Akses tanggal 16 Juni 2011.

Jones, D.T. dan A. H. Prasetyo. 2002. A Survey of the Termites (Insecta:Isoptera) of Tabalong District, South Kalimantan, Indonesia. The Raffles Bulletin of Zoology 2002 50(1): 117-128.

Kalshoven, L.G.E. 1981. Pests of Crops in Indonesia. PT. Ichtiar Baru-Van Hoeve. Jakarta.
Kartika, T., S. Yusuf, D. Tarmadi, A. H. Prianto dan I. Guswenrivo. 2007. Pengembangan Formula Bahan Infeksi Cendawan sebagai Alternatif Biokontrol Rayap Tanah Coptotermes sp. Jurnal Ilmu dan Teknologi Kayu Tropis Vol. 5, No. 2: 63-67.

Martawijaya, A., I. Kartasujana, Y.I. Mandang., S.A. Prawira dan K. Kadir. 1989. Atlas Kayu Indonesia Jilid II. Balai Penelitian dan Pengembangan Kehutanan. Bogor.

Nandika, D., Y. Rismayadi dan F. Diba. 2003. Rayap : Biologi dan Pengendaliannya. Universitas Muhammadiyah Press. Surakarta.

Oka, I. N. 1995. Pengendalian Hama Terpadu dan Implementasinya di Indonesia. Gadjah Mada University ress

Owusu, E.O., K.S. Akutse dan K. Afreh-Nuamah. 2008. Effect of some traditional plant com-ponents on the control of termites, Macrotermes spp. (Isoptera; Termitidae). African Journal of Science and Technology (AJST) Science and Engineering Series Vol. 9, No. 2: 82-89.

Pracaya. 2003. Hama dan Penyakit Tanaman. Penebar Swadaya Anggota IKAPI.

Rayati, D. J. dan W. Widayat. 2006. Patogenitas Jamur Beauveria bassiana, Metarrhizium anisopliae dan Peacilomyces fumosoroseus terhadap Rayap pada Tanaman Teh. Jurnal Penelitian Teh dan Kina Vol.9, No.1-2: 15-20.

Suin, N. M. 1992. Rayap Kayu di Hutan Pendidikan dan Penelitian Biologi Universitas Andalas. Jurnal Matematika dan Pengetahuan Alam, Vol.2,No.1:25-35. 